\title{
SWEET GRAPE MINI TOMATO GROWN IN CULTURE SUBSTRATES AND EFFLUENT WITH NUTRIENT COMPLEMENTATION
}

\section{ANANDA H. N. CUNHA, DELVIO SANDRI, JONAS A. VIEIRA, THIAGO B. CORTEZ, THIAGO H. DE OLIVEIRA}

\begin{abstract}
The objective of this study was to evaluate production of Sweet Grape mini tomato (Lycopersicum esculentum Mill.) using culture substrates and nutrient solution sewage effluent, applied by drip irrigation (fertigation). The experiment was conducted at the University of Goiás State (UEG-UnUCET), from June to November 2011 in Anápolis-GO, Brazil. The experimental design was a $2 \times 3$ factorial arrangement in a randomized complete block design with four repetitions. The plots were made by combining two nutrient solutions, effluent supplemented with mineral fertilizers (EcS); conventional nutrient solution (SnC); in addition three cultivation substrates: $60 \%$ of fine sand washed $+40 \%$ substrate composed by $20 \%$ coconut fiber plus $80 \%$ pine bark (S1); $20 \%$ coconut fiber and $80 \%$ pine bark (S2) and natural coconut fiber (S3). Sewage effluent were determined nitrate, calcium, potassium, manganese, total phosphate, total iron, magnesium, chloride, sulphate, boron, zinc and molybdenum. We evaluated average mass and average number of fruits per bunch, total fruit and total yield per plant. Statistical difference absence among tested solutions indicates sewage effluent can be used as an alternative source of nutrients in growing mini tomatoes in hydroponics.
\end{abstract}

KEYWORDS: mini tomato; nutrient solution; reuse.

\section{TOMATE SWEET GRAPE CULTIVADO EM SUBSTRATOS DE CULTIVO E EFLUENTE COM COMPLEMENTAÇÃO DE NUTRIENTES}

RESUMO: O objetivo do trabalho foi avaliar a produção do minitomate (Lycopersicum esculentum Mill.) variedade Sweet Grape, empregando substratos de cultivo e solução nutritiva de efluente de esgoto, aplicada por gotejamento. O experimento foi realizado na Universidade Estadual de Goiás (UEG-UnUCET), de junho a novembro de 2011 em Anápolis, Goiás. O delineamento experimental foi em esquema fatorial $2 \times 3$, em blocos casualizados, com quatro repetições. As parcelas foram constituídas pela combinação de duas soluções nutritivas, efluente complementado com fertilizantes minerais - EcS e solução nutritiva convencional - SnC, e três substratos de cultivo, com $60 \%$ de areia fina lavada $+40 \%$ de substrato composto de $20 \%$ de fibra de coco e $80 \%$ de casca de pínus (S1); $20 \%$ de fibra de coco e $80 \%$ de casca de pínus (S2) e fibra de coco natural (S3). No efluente de esgoto, foram avaliados nitrato, cálcio, potássio, manganês, fosfato total, ferro total, magnésio, cloreto, sulfato, boro, zinco e molibdênio. Avaliaram-se a massa média e o número médio de frutos por cacho, o número total de frutos e a produção total por planta. A ausência de diferença estatística entre as soluções testadas indica que o efluente de esgoto pode ser utilizado como fonte alternativa de nutrientes no cultivo do minitomate em hidroponia.

PALAVRAS-CHAVE: minitomate; solução nutritiva; reúso.

\footnotetext{
1 Engenheira Agrônoma, Doutoranda em Agronomia, Escola de Agronomia, Universidade Federal de Goiás, UFG/Goiânia - Goiás, Fone (62) 3521-1542, analena23@gmail.com

2 Eng. Agrícola, Prof. Doutor, Faculdade de Agronomia e MedicinaVeterinária, UnB/Brasília - DF, sandri@unb.br

3 Químico, Prof. Doutor, Universidade Estadual de Goiás, UEG/Anápolis - GO, jonas@ueg.br

4 Estudante de Engenharia Agrícola, Universidade Estadual de Goiás, UEG/Anápolis - GO, thiagocortez2@hotmail.com

5 Engenheiro Agrícola, Universidade Estadual de Goiás, UEG/Anápolis - GO, tthiagua@hotmail.com

Recebido pelo Conselho Editorial em: 10-7-20131
}

Aprovado pelo Conselho Editorial em: 3-3-2014 


\section{INTRODUCTION}

Sweet Grape tomato is produced, primarily, in Midwest and Southeast Brazil. In this context, farmers from Goiania and Anápolis are looking for new planting options in relation to traditional crops to obtain more profit on tight deadlines.

Mini tomatoes produced hydroponically and under protected environment are one of the crops that provide fast economic return (CARON et al., 2013) and their consumption has increased significantly in recent years, encouraging farmers to cultivate (ABRAHÃO et al., 2011). Therefore, the target variety has aroused great interest among farmers due to a promising market (AGUIAR et al., 2012); an excellent diversification alternative that associated with wastewater reuse might decrease production costs (RINALDI et al., 2013).

Sewage effluent has a high concentration of essential nutrients to crop production; thus, providing a feasible alternative to mineral fertilizer economy and reducing environment problems (CORRÊA et al., 2010) and nutrient solution preparation in hydroponic production. According to MELO et al. (2009), treated wastewater is rich in dissolved salts, which are essential to plants, therefore, can be used as nutrient solution, even if complementation is needed by the plant demand.

Various substrates can be used to produce hydroponic mini tomatoes in different culture environments, which is an important factor in water and salt availability to plant. An increase yield and fruit quality may come from cultivation on substrates in hydroponics (SCHULZ, 2009) as provides the proper amount of nutrients for each crop stage (CHARLO et al., 2009).

Nutrient solution via hydroponics has many advantages compared to conventional fertilizer: joint application with water, high nutrient absorption, and improved distribution and splitting, observing application via drip irrigation, enabling satisfactory performance in nutrient absorption by plants (RAGOZO et al., 2009).

Some environmental benefits of using sewage effluent in hydroponics are: clear reduction of pesticide use (no herbicide use, reduced of insecticides and fungicides), once it is performed under protected environment, i.e., greenhouse or nursery (FACTOR et al., 2008); avoid fountainhead pollution issue, caused by fertilizer loading in soil and erosion processes (MELO et al., 2009).

To minimize agriculture impacts on water resources, many countries have demonstrated feasibility of using sewage effluents in farming (SANTOS et al., 2012). Thus, effluents may be employed in various crops, among them (RINALDI et al., 2013) tomato, which as it is an important crop, its hydroponic production is facilitated when using substrate, allowing greater support and ease of management in nutrient solution application (especially when it is spotted FACTOR et al., 2008). The most appropriate water management (CUNHA et al. 2011a), nutrient supply (ABRAHÃO et al., 2011), as well as reduced salinity (PACCO et al., 2012) plant health problems and production losses (ASSIS et al., 2011) are some the advantages of growing substrates against soil cropping systems.

Researches were carried out with various substrates such as coconut husk fiber (CHARLO et al., 2009; ABRAHÃO et al., 2011 and CUNHA et al., 2011b); coffee husk waste compost (ASSIS et al., 2011); organic waste compost (BEZERRA et al., 2009); substrate treated with sewage sludge (CORREAA et al., 2010), pickled palm heart production waste (FERMINO et al., 2010); and washed sand (BRAUN et al., 2010). Nevertheless, considering availability, cost reduction, and accumulation in environment, agricultural and municipal waste use as substrate has been investigated.

The objective of this work was to evaluate performance of mini Sweet Grape tomato grown in substrates and irrigated with nutrient solution prepared by treated sewage effluent, designated only as "effluent". 


\section{MATERIAL AND METHODS}

The study was conducted in the University of Goiás State (UEG), at the College of Engineering and Technological Sciences (UnUCET) in Anápolis, Goiás, Campus Henrique Santillo, on BR 153 highway, at $n^{\circ} 3.105$. The area is located at $16^{\circ} 20^{\prime} 34^{\prime \prime}$ South and $48^{\circ} 52^{\prime}$ 51" West, at 997 m altitude. According to Köppen, the city of Anápolis - GO shows Aw climate, with warm climatic conditions, humid to semi-arid, and the seasonal tropical climate with well-defined rainfall patterns, i.e., rainy season from October to March and dry season from April to September. The average annual air temperature is $25.0{ }^{\circ} \mathrm{C}$, and the month of June has the lowest air average temperature $\left(20.5{ }^{\circ} \mathrm{C}\right.$ ), while the month of September has the highest average temperature (31.4 ${ }^{\circ} \mathrm{C}$ ). The average annual rainfall is $1750 \mathrm{~mm}$ and relative humidity is $61 \%$.

Relative humidity data were recorded using a digital hygrometer; model THG312, Oregon Scientific brand, throughout all the crop cycle. The temperature was monitored daily at 2:00 p.m., with measurements taken at the plant height employing a maximum and minimum thermometer, Incoterm brand.

Sweet Grape tomato seeds came from Sakata Seed Sudamérica Ltd company. This variety has large expansion in consumer market with added value in Anápolis-GO and shows resistance to some fungi and viruses. Seeds were sown in May and obtained in PVC trays with 128 cells using coconut fiber substrate. They came from a specialized nursery, located in Leopoldo de Bulhões GO. Transplant was made about 40 days after sowing (June 17), i.e., seedlings with six expanded leaves. The experiment was performed between June and November 2011.

The experimental design was held in randomized blocks in a 2 x 3 factorial design, resulting in six treatments with four replications, totaling twenty-four plots. Each plot consisted of two rows of plants (total of 10 useful plants), except for boundary plants that had three lines and an extra plant over all plots, with the bottom line and on-line plant serving as margin. The treatments were a combination of two nutrient solutions: effluent supplemented with mineral fertilizers (EcS) and conventional nutrient solution (SnC). Regarding substrates, three cultivation were used: 60\% washed fine sand $+40 \%$ compound substrate (20\% coconut fiber and $80 \%$ pine bark) (S1) Tropstrato@; 20\% coconut fiber and 80\% pine bark (S2) - Tropstrato@; and 100\% natural coconut fiber (S3) - Golden Mix $($. Resulting in the following treatments: $\mathrm{T} 1=\mathrm{EcS} \mathrm{S1}$; $\mathrm{T} 2$ = EcS S2; $\mathrm{T} 3=$ EcS S3; T4 = SnC S1; T5 = SnC S2 e T6 = SnC S3.

Fine sand had 0.05 to $0.42 \mathrm{~mm}$ of grain size; Tropstrato@ and the Golden Mix@ were obtained in local market. The analysis of $\mathrm{pH}$, EC, CRA, maximum density and moisture for substrate 1 were made according to KÄMPF, et al. (2006) methods. For substrates 2 and 3, we used the pre-determined values by producer that were informed on product packaging. Substrates have the following initial characteristics that are described in Table 1.

TABLE 1. Initial characteristics of used substrates for mini tomato cultivation.

\begin{tabular}{|c|c|c|c|}
\hline \multirow{2}{*}{ Characteristics } & \multicolumn{3}{|c|}{ Substrates } \\
\hline & S1 & $\mathrm{S} 2^{1}$ & $\mathrm{~S}^{2}$ \\
\hline $\mathrm{pH}$ & 5.8 & 5.7 & 6.0 \\
\hline Electrical conductivity (dS cm-1) & 1.8 & 1.3 & 0.7 \\
\hline Water retention capacity (weight weight ${ }^{-1}$ ) & 150 & 140 & 400 \\
\hline Density $\left(\mathrm{kg} \mathrm{m}^{-3}\right)$ & 480 & $1,041.70$ & 90 \\
\hline Maximum humidity $\left(\mathrm{p} \mathrm{p}^{-1}\right) \%$ & 60 & 50 & 55 \\
\hline
\end{tabular}

${ }^{1}$ Tropstrato. ${ }^{2}$ Golden Mix.

Sewer from UnUCET/UEG was treated using a system of three modified septic tank in series with working volume of 12,500; 8,000 and 4,000 L, respectively. Then, effluent was transferred to three wetland beds with cultivation of Typha sp (Taboa) macrophyte. The wetland beds had $6 \mathrm{~m}$ length, $2 \mathrm{~m}$ width and $1 \mathrm{~m}$ depth, disposed in parallel and with subsurface flow. As means of plant 
supporting in each wetland bed, we used crushed stone \#2, washed gravel, natural gravel with $50 \%$, $43 \%$ and 56\%, porosity and 5,400 L; 4,644 L; 6,048 L useful volume, respectively. Natural water was withdrawn from a semi-artesian well, and stored in 2,000-L polyethylene boxes.

Two nutrient solutions, with a prepared effluent and enriched with mineral fertilizers (EcS) and the other a conventional one prepared with well water $(\mathrm{SnC})$ were used. Mineral fertilizers were added to the effluent to match conventional solution composition (SnC). Nutrient solutions were applied in accordance with two stages of plant cycle; where stage 1 is from transplanting until 45 days after transplanting (DAT) (Table 2); and stage 2 is at 45 DAT until the crop cycle end (Table 2).

TABLE 2. Fertilizer quantity and recommended nutrient concentration for the two cycle stages for Sweet Grape mini tomatoes.

\begin{tabular}{|c|c|c|}
\hline Fertilizers & $\begin{array}{c}\text { Stage } 1^{1} \\
\left.\text { Quantity (g } 1000 \mathrm{~L}^{-1}\right)\end{array}$ & $\begin{array}{c}\text { Satge } 2^{2} \\
\text { Quantity }\left(\mathrm{g} 1000 \mathrm{~L}^{-1}\right)\end{array}$ \\
\hline Calcium nitrate & 500 & 650 \\
\hline Potassium nitrate & 170 & 170 \\
\hline Potassium chloride & 0 & 170 \\
\hline Rexolin (BRA) & 25 & 25 \\
\hline Yara iron M48 & 10 & 10 \\
\hline Potassium sulfate & 200 & 300 \\
\hline Nutrients & $\begin{array}{l}\text { Concentration } \\
\left(\text { g } 1000 \mathrm{~L}^{-1} \text { ) }\right.\end{array}$ & 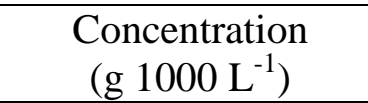 \\
\hline Nitrate & 79.5 & 97.5 \\
\hline Calcium & 85.0 & 110.5 \\
\hline Chlorine & 0 & 70.5 \\
\hline Potassium & 213.8 & 332.8 \\
\hline Zinc* & 1.05 & 1.05 \\
\hline Iron & 1.5 & 1.5 \\
\hline Manganese* & 0.8 & 0.8 \\
\hline Boron* & 0.375 & 0.375 \\
\hline Sulphur & 79.88 & 58.87 \\
\hline Molybdenum* & 0.0125 & 0.0125 \\
\hline Phosphorus & 114.4 & 114.4 \\
\hline Magnesium & 35 & 45 \\
\hline
\end{tabular}

Table 3 shows the average values of effluent chemical analysis before nutrient solution preparation of enriched effluent with mineral fertilizers plus added amount (CUNHA et al., 2014a). We observed that calcium, chloride and sulfate have higher values than the others do, this allowed adding smaller amounts (1.35; 0.59 and $1.37 \mathrm{~kg}$, respectively). Regarding the added amount (Table 3 ), we should highlight nitrate, potassium and phosphate, as they are required in large amounts by plants for being essential macronutrients and they were not found in sufficient quantities in the effluent, requiring larger quantities (4.02; 12.26 and $3.73 \mathrm{~kg}$, respectively), compared to sulfate, calcium and chloride (Table 3). 
TABLE 3. Mean values of quantitative chemical analysis of the effluent before preparation of nutrient solution and the added amount.

\begin{tabular}{ccc}
\hline Analyzed parameter & Concentration $\left(\mathrm{mg} \mathrm{L}^{-1}\right)$ & Added amount* $(\mathrm{kg})$ \\
\hline Nitrate & 6.95 & 4.02 \\
Calcium & 92.46 & 1.35 \\
Chloride & 141.19 & 0.59 \\
Potassium & 16.30 & 12.26 \\
Zinc & 0.40 & 0.0022 \\
Total iron & 0.17 & 0.05 \\
Manganese & 0.60 & 0.02 \\
Boron & 0.10 & 0.01 \\
Sulfate & 56.71 & 1.37 \\
Molybdenum & 2.12 & 0.00 \\
Total phosphate & 18.81 & 3.73 \\
Magnesium & 25.43 & 1.34 \\
\hline
\end{tabular}

*During all cycle at the volume of 327 liters.

Nutrient solution applications were made by drip irrigation at the following schedule: 6:00 a.m., 9:00 a.m., 11:00 a.m., 12:00 p.m., 1:00 p.m., 2:00 p.m., 3:00 p.m. and 6:00 p.m., established by preliminary tests according to substrate retention capacity. During first two day applications, dripping was left for four minutes; from the third to the seventh for five minutes and the eighth for eight minutes, totaling 41 daily minutes without returning nutrient solution. Solutions application time was controlled by a timer triggered to pumps through switches at predetermined times. The total volume of nutrient solution applied per pot during the experiment was $327 \mathrm{~L}$ or $6694 \mathrm{~mm}$ cycle $^{-1}\left(96.7 \mathrm{~mm} \mathrm{day}^{-1}\right)$.

We used black polyethylene pots with $17.8 \mathrm{~cm}$ top and $13.0 \mathrm{~cm}$ diameters, 16-cm height, where total volume is $8 \mathrm{~L}$ and $7 \mathrm{~L}$ useful L. Pots were accommodated on bricks to avoid contact with soil and reduce diseases occurrence, each pot received only one seedling.

Fruits were harvested at physiological ripeness considering their coloration based on a harvest standard recommended by JUNQUEIRA et al. (2011). Tomatoes were transported in plastic bags to the Laboratories of Agricultural Engineering and Analytical Chemistry of UnUCET / UEG for qualitative and quantitative analysis. All fruits were weighed, including those with cracks or other damage, such as pest attacks or disease symptoms being commercially avoided.

Since transplantation, Sweet Grape mini tomato cycle was 170 days, and harvest began at 60 DAT, in 16 samples. We evaluated the following parameters: average number of fruits per bunch; total number of fruits; total yield and fruit mass, using semi-analytical balance BL 320 Shimadzue brand with precision of $0.01 \mathrm{~g}$.

Quantitative data were subjected to variance analysis sing the $\mathrm{F}$ test and when they were significant, there was average comparison by Tukey test at $1 \%$ and $5 \%$ significance level, using the software Sisvar (FERREIRA, 2011).

\section{RESULTS AND DISCUSSION}

Air temperatures in Anápolis were $14.57^{\circ} \mathrm{C}$ (lowest average) and $31.41{ }^{\circ} \mathrm{C}$ (highest average). The highest relative humidity (RH) during the crop cycle between June and July was $50 \%$. Humidity and air temperature measures are important to grow tomatoes in greenhouses (HOLCMAN et al., 2011).

Table 4 shows the analysis of variance and "F" test at 1 and 5\% probability, which shows that there was a significant difference in total number of fruits, both for the substrate and for the interaction. 
TABLE 4. Variance analysis of average mass, average number of fruits per bunch, total fruit and total production.

\begin{tabular}{|c|c|c|c|c|c|}
\hline \multirow[b]{2}{*}{ VF } & \multirow[b]{2}{*}{ FD } & \multicolumn{4}{|c|}{ RMS } \\
\hline & & $\begin{array}{l}\text { Average } \\
\text { mass }\end{array}$ & $\begin{array}{l}\text { Average number of fruits per } \\
\text { bunch }\end{array}$ & $\begin{array}{c}\text { Total } \\
\text { number of } \\
\text { fruit }\end{array}$ & $\begin{array}{c}\text { Total } \\
\text { production }\end{array}$ \\
\hline $\begin{array}{l}\text { Nutrient solution } \\
\text { (A) }\end{array}$ & 1 & 0.62 & 24.00 & $9,361.5$ & 20.53 \\
\hline Substrate (B) & 2 & 0.001 & 8.16 & $473,403.20 *$ & 8.50 \\
\hline$A \times B$ & 2 & 1.03 & 2.00 & $156,150.00 *$ & 38.65 \\
\hline Blocks & 3 & 0.74 & $32.11^{*}$ & $371,434.50$ & 17.97 \\
\hline Residue & 15 & 1.42 & 7.64 & $434,112.90$ & 25.60 \\
\hline Total & 23 & - & - & - & - \\
\hline Average & - & 9.16 & 34.16 & $3,572.25$ & 37.90 \\
\hline Standard deviation & - & 1.06 & 3.33 & 870.17 & 4.90 \\
\hline VC (\%) & - & 13.02 & 8.09 & 18.44 & 13.35 \\
\hline
\end{tabular}

**Significant at $1 \%$ and *Significant at $5 \%$ by Tukey test.

Average fruit mass of mini tomato was $9 \mathrm{~g}$ per fruit and showed no significant differences ( $>0.01$ ) among nutrient solution types and substrates (Table 5). This value was higher than those obtained by ABRAHÃO (2011), with 7.9 g per fruit when testing six relations among $\mathrm{K}, \mathrm{Ca}, \mathrm{Mg}$ on yield and quality of mini tomato grown in substrate. Meanwhile, they were lower as SAKATA (2012) and JUNQUEIRA et al. (2011), which indicate values between 10 and 20 g. Nonetheless, one of the important factors taken into consideration when marketing is number of fruits per container, which are references to classify, since it combines weight and quantity as classification parameters. It is noteworthy that was not measured by the amount of fruit packaging, but it can be observed that the product is sold in boxes containing 200 to 300 grams (AGUIAR et al., 2012), i.e., about 20 fruit of 15 grams each.

Although the average fruit values have been somewhat lower, as the ones given by SAKATA (2012), it does not interfere with their marketing. The average number of fruits per bunch obtained ranged between 31 and 36 (Table 5). Despite this parameter does not show differences between treatments, we noted influences on total number of fruits (36 fruits per bunch with 4,620 fruits in T1).

Number of fruit per plant during growing cycle was longer comparing S1 to S2 and S3 to EcS solution, which is justified by S1 to S2 and S3 composition ratios, i.e., S1 can provide a larger number of fruits per plant (Table 5).

For SnC values of S1 and S2 were higher to S3 presented, where it combined with used solution characteristic is the least recommended, as it presented less fruit for the two tested solutions. Probably by the fact that it blocked nutrients to plant due to its composition and high salt retention (CUNHA et al., 2011b), affecting production. Even substrate has shown a better water holding capacity (PACCO et al., 2012) when compared to the other.

Assuming that, S1 had greater number of fruits for the two solutions, beings the most indicated. AS S1 is composed by sand mixed with substrate based on coir and pine bark differs from other substrate composition, which may have promoted the difference in production. It has possibly favored adequate nutrient availability, reflecting on greater absorption and consequently raised production. Even though other studies have shown that sand has lower water holding capacity (CUNHA et al., 2011b) and low porosity (BRAUN et al., 2010). 
TABLE 5. Average values of mass, number of fruits per bunch, total number of fruits and total production of Sweet Grape mini tomatoes for different types of nutrient solution and substrate.

\begin{tabular}{|c|c|c|c|}
\hline \multirow[t]{2}{*}{ Nutrient solution } & \multicolumn{3}{|c|}{ Substrates } \\
\hline & $\mathrm{S} 1$ & S 2 & S 3 \\
\hline & \multicolumn{3}{|c|}{ Average mass (g fruto-1) } \\
\hline EcS & 8.81 Аa & 8.79 Aa & $9.42 \mathrm{Aa}$ \\
\hline \multirow[t]{2}{*}{$\mathrm{SnC}$} & 9.55 Аа & $9.52 \mathrm{Aa}$ & 8.91 Аа \\
\hline & \multicolumn{3}{|c|}{ Average number of fruit per bunch } \\
\hline EcS & $36 \mathrm{Aa}$ & $34 \mathrm{Aa}$ & $34 \mathrm{Aa}$ \\
\hline \multirow[t]{2}{*}{$\mathrm{SnC}$} & 34 Аа & 33 Аа & 31 Аа \\
\hline & \multicolumn{3}{|c|}{ Total number of fruit } \\
\hline EcS & 4,620 Аа & $3,050 \mathrm{Bb}$ & 3,100 Ba \\
\hline \multirow[t]{2}{*}{$\mathrm{SnC}$} & 4,298 Aa & 3,290 Аа & 3,069 Ba \\
\hline & \multicolumn{3}{|c|}{ Total production (Kg) } \\
\hline EcS & $38.0 \mathrm{Aa}$ & $35.4 \mathrm{Aa}$ & $37.4 \mathrm{Aa}$ \\
\hline SnC & $37.8 \mathrm{Aa}$ & $42.3 \mathrm{Aa}$ & 36.3 Аa \\
\hline
\end{tabular}

Results obtained by ABRAHÃO (2011) show a number of fruits plant ${ }^{-1}$ similar to ours (Table 5), showing significant differences in S3 than other substrates. It is believed that it has been influenced by the white fly attack and occurrence of white mold detected at 120 DAT. In this work values between 329 and 429 fruits per plant were obtained (3290 to 4298 total fruits on ten useful plants), with a coefficient of variation (18.44\%) close to value submitted by HOLCMAN et al., (2011) (18.19 \%), which found a total number of 390 Sweet Grape tomato fruits on average.

The total yield for the 177 DAT cycle Sweet Grape mini tomatoes was 3.54 to $4.23 \mathrm{~kg} \mathrm{plant}^{-1}$ (Table 5) and, corresponding to 71 to $85 \%$ of that obtained by local farmers. According to SAKATA (2012), a production of $5 \mathrm{~kg} \mathrm{plant}^{-1}$ within a six to eight month cycle (180 to 240 DAT) is considered ideal for Anápolis and Goiânia region. The production obtained by HOLCMAN (2010) was similar to the study that was approximately $3.5 \mathrm{~kg}$ plant ${ }^{-1}$ for same tomato variety.

It is noteworthy that the work produced tomatoes with use of effluent that is an alternative source of nutrients and provides this solution (CUNHA et al., 2014b) and production costs were lower when compared with conventional production. Noting that, as judged by CUNHA et al., (2014a) showed $40 \%$ reduction in production costs, expected better economic return, once the fruits are produced with same quantity and quality compared to conventional.

\section{CONCLUSIONS}

S1 substrate has a better production compared to other substrates.

The lack of statistical difference among tested solutions indicates that sewage effluent can be used as an alternative source of nutrients in growing mini tomatoes in hydroponics.

\section{REFERENCES}

ABRAHÃO, C. Relação K:Ca:Mg na solução nutritiva para cultivo de mini tomate em substrato. 2011. 86f. Dissertação (Mestrado em Agronomia). Faculdade de Ciências Agronômicas, Universidade Estadual Paulista, Botucatu, 2011. 
ABRAHÃO, C.; VILLAS BÔAS, R. L.; KOYANAGUI, M. T.; TREMOCOLDI, M. A.; EVANGELISTA, R. M. Efeito de diferentes relações $\mathrm{K}: \mathrm{Ca}: \mathrm{Mg}$ na qualidade de frutos de mini tomate cultivados em substrato. Horticultura Brasileira, Brasília, n. 29. p. 5226-5231, jul 2011. Suplemento. CD-ROM.

AGUIAR, F. P. C.; ABRAHÃO, R. M. S.; ANJOS, V. D. A.; BENATO, E. A. P. Determinação da vida útil de tomate tipo cereja e 'Sweet Grape'. 2012. Disponível em:

$<$ http://www.cnpma.embrapa.br/eventos/2012/ciic/cd_anais/Artigos/re12218.pdf>. Acesso em : 10 set. 2013.

ASSIS, A. M.; UNEMOTO, L. K.; YAMAMOTO, L. Y.; LONE, A. B.; SOUZA, G. R. B.; FARIA, R.T.; ROBERTO, S. R.; TAKAHASHI, L. S. A. Cultivo de orquídea em substratos à base de casca de café. Bragantia, Campinas, v. 70, n. 3, 544-549 p. 2011.

BEZERRA, F. C.; FERNANDO, V. M. F.; SILVA, T. C. Produção de mudas de berinjela em substrato à base de resíduos orgânicos e irrigadas com água ou solução nutritiva. Horticultura Brasileira, Brasília, v. 27, n. 2, p. S1348-S1352, 2009. Suplemento. CD-ROM.

BRAUN, H.; CAVATTE, P. C.; AMARAL, J. A. T.; AMARAL, J. F. T.; REIS, E. F. Produção de mudas de tomateiro por estaquia: efeito do substrato e comprimento de estacas. Idesia, Chile, v. 28, p. 9-15, abr. 2010.

CARON V. C.; TESSMER M. A.; MELLO S. C.; JACOMINO A. P. 2013. Quality of mini tomatoes harvested at two maturity stages and kept chilled in three packages. Horticultura Brasileira, Brasília., v. 31, n. 2, p. 279-286, abr./jun. 2013.

CHARLO, H. C. O.; CASTOLDI, R.; FERNANDES, C.; VARGAS, P. F.; BRAZ L. T. Cultivo de híbridos de pimentão amarelo em fibra da casca de coco. Horticultura Brasileira, Brasília, v. 27, n. 2, p. 155-159, abr./jun. 2009.

CORRÊA, R. S.; SILVA, L. C. R.; BAPTISTA, G. M. M.; SANTOS, P. F. Fertilidade química de um substrato com lodo de esgoto e composto de resíduos domésticos. Engenharia Agrícola $e$ Ambiental, Campina Grande, v.14, n.5, p. 538-544, 2010.

CUNHA, A. H. N.; VIEIRA, J. A.; CORTEZ, T. B. Avaliação da água residuária para reutilização em fertirrigação. In: SIMPÓSIO NACIONAL DE CIÊNCIA E MEIO AMBIENTE, 2, 2011, Anápolis. Anais... Anápolis: Centro Universitário de Anápolis, 2011a. CD-ROM.

CUNHA, A. H. N.; FERREIRA, R. B.; VIEIRA, J. A.; PACCO, H. C.; SANDRI, D. Avaliação do pH e condutividade elétrica de diferentes substratos para hidroponia. In: SEMINÁRIO DE INICIAÇÃO CIENTÍFICA, 9; JORNADA DE PESQUISA E PÓS-GRADUAÇÃO; SEMANA NACIONAL DE CIÊNCIA E TECNOLOGIA, 6, 2011. Anais... Anápolis: Universidade Estadual de Goiás, 2011b. CD-ROM.

CUNHA, A. H. N.; SANDRI, D.; VIEIRA, J. A.; ALVES, J. A. A.; CUNHA, I. N. Uso de efluente para complementação de nutrientes no cultivo de Sweet Grape. In: CONGRESSO BRASILEIRO DE ENGENHARIA AGRÍCOLA - CONBEA, 43, 2014. Anais... Campo Grande: Centro de Convenções 'Arquiteto Rubens Gil de Camilo', Sociedade Brasileira de Engenharia Agrícola, 2014a. CD-ROM.

CUNHA, A. H. N.; COSTA, L. F. dos S.; FERREIRA, E. P. de B.; FERNANDES, E. P. B. Nutritional potential of rock dust ash cane and treated effluent. In: International Symposium AgroEnviron, 9, 2014. Anais...Goiânia: Centro Cultural Oscar Niemeyer, Universidade Federal de Goiás, 2014b. CD-ROM.

FACTOR, T. L.; ARAÚJO, J. A. C.; VILLELA JÚNIOR, L. V. E. Produção de pimentão em substratos e fertirrigação com efluente de biodigestor. Engenharia Agrícola e Ambiental, Campina Grande, v.12, n.2, 143-149 p. 2008. 
FERMINO M. H; GONÇALVES R. S.; BATTISTIN A; SILVEIRA J. R. P; BUSNELLO A. C; TREVISAM M. Aproveitamento dos resíduos da produção de conserva de palmito como substrato para plantas. Horticultura Brasileira, Brasília, v. 28, 282-286 p. 2010.

FERREIRA, D. F. Sisvar: a computer statistical analysis system. Ciência e Agrotecnologia, Lavras, v. 35, n. 6, 1039-1042 p. 2011.

HOLCMAN, E. Microclima e produção de tomate tipo cereja em ambientes protegidos com diferentes coberturas plásticas. Disponível em: <http://www.cbmet2010.com/anais/artigos/119_53470.pdf>. Acesso em: 25 nov. 2013.

HOLCMAN, E.SENTELHAS, P. C.; MELLO, S. da C. Modelos para estimativa da produtividade e do número de frutos de tomateiro tipo cereja, cultivado sob diferentes coberturas plásticas. In: CONGRESSO BRASILEIRO DE AGROMETEOROLOGIA, 27, 2011, Guarapari. Anais... Guarapari: SESC Centro de Turismo de Guarapari, 2011. CD-ROM.

JUNQUEIRA, A. H.; PEETZ, M. S.; ONODA, S. M. SWEET GRAPE: Um modelo de inovação na gestão da cadeia de produção e distribuição de hortaliças diferenciadas no Brasil. Abril 2011. 19p. Disponível em:

<http://www.espm.br/Publicacoes/CentralDeCases/Documents/SWEET\%20GRAPE.pdf>. Acesso em: 12 jan. 2012.

KÄMPF, A. N.; TAKANE, R. J.; SIQUEIRA, P. T. V. Floricultura: técnicas de preparo de substratos. Brasília: LK Editora e Comunicações, 2006. 132 p.

MELO, H. N. S.; PIFER, R. C.; ANDRADE NETO, C. O.; MARQUES JÚNIOR, J. Utilização de nutrientes de esgoto tratado em hidroponia. In: MOTA, F. S.; VON SPERLING, M. Nutrientes de esgoto sanitário: utilização e remoção. Rio de Janeiro: Associação Brasileira de Engenharia Sanitária - ABES, 2009. 428 p.

PACCO, H. C.; SANDRI, D.; AVELINO NETO, S.; CUNHA, A. H. N. Retenção de água em diferentes substratos utilizados na cultura de hortaliças. In: CONGRESO LATINOAMERICANO Y DEL CARIBE DE INGENIERÍA AGRÍCOLA, 10, CONGRESSO BRASILEIRO DE ENGENHARIA AGRÍCOLA CLIA/CONBEA, 41, 2012, Londrina. Anais... Londrina: Associação Brasileira de Engenharia Agrícola, 2012. CD-ROM.

RAGOZO, C. R. A.; BULL, L. T.; VILLAS BÔAS, R. L.; DUENHAS, L. H. Avaliação dos teores nutricionais em laranjeira 'Valência', sob fertirrigação. Irriga, Botucatu, v. 14, n. 1, 23-31 p. jan./mar. 2009.

RINALDI, M. M.; THEBALDI, M. S.; ROCHA, M. S.; SANDRI, D.; FELIZBERTO, A. B. Qualidade pós-colheita do tomate irrigado por diferentes sistemas de irrigação e qualidades de água. Irriga, Botucatu, v. 18, 59-72 p. 2013.

SAKATA. Seed Sudamerica. Disponível em: <http://www.sakata.com.br/institucional/>. Acesso em: 12 jan. 2012.

SANTOS, J. G.; PIVELI, R. P.; CAMPOS, F; SUNDEFELD G; SOUSA, T. S.; CUTOLO, S.A. Análise parasitológica em efluente de estações de tratamento de águas residuárias. Patologia Tropical, Goiânia, v. 41, n. 3, 319-336 p. jul.-set. 2012.

SCHULZ, A. Produção hidropônica de pepino japonês em função de recipientes e densidades de plantio. In: ENCONTRO BRASILEIRO DE HIDROPONIA, 2, 2009. Disponível em: <http://www.portalhidroponia.com.br> Acesso em: 16 nov. 2010. 